\title{
Efficacy, Tolerability, and Safety of Lanthanum Carbonate in Hyperphosphatemia: A 6-Month, Randomized, Comparative Trial versus Calcium Carbonate
}

\author{
A.J. Hutchison ${ }^{a} \quad$ B. Maes ${ }^{\text {b }} \quad$ J. Vanwalleghem ${ }^{c} \quad$ G. Asmus ${ }^{d} \quad$ E. Mohamed ${ }^{\text {e }}$ \\ R. Schmieder ${ }^{f}$ W. Backs ${ }^{g}$ R. Jamar ${ }^{h}$ A. Vosskühler ${ }^{i}$ \\ ${ }^{a}$ Manchester Institute of Nephrology and Transplantation, The Royal Infirmary, Manchester, UK; \\ ${ }^{\mathrm{b}}$ Universitair Ziekenhuis Gasthuisberg, Leuven, Belgium; ' ${ }^{\mathrm{V}}$ Virga Jesse Ziekenhuis, Hasselt, Belgium; \\ ${ }^{\mathrm{d}} \mathrm{KfH}$-Dialysezentrum, Berlin, Germany; ${ }^{e}$ Freeman Hospital, Newcastle upon Tyne, UK; \\ ${ }^{\mathrm{f}}$ Friedrich-Alexander-Universität Erlangen-Nürnberg, Erlangen, Germany; ${ }^{9}$ Dialysezentrum Barmbek, Hamburg, \\ Germany; ${ }^{h}$ Imelda Ziekenhuis, Bonheiden, Belgium; ' $\mathrm{KfH}$-Dialysezentrum, Bottrop, Germany
}

\section{Key Words}

Lanthanum carbonate $\cdot$ Phosphate $\cdot$ Phosphate binders ·

Calcium carbonate $\cdot$ Hypercalcemia $\cdot$ Hemodialysis

\begin{abstract}
Background/Aims: Hyperphosphatemia is an important clinical consequence of renal failure, and its multiple adverse systemic effects are associated with significantly increased risks of morbidity and mortality in dialysis patients. Existing oral phosphate binders have not permitted control of serum phosphate within currently accepted guidelines. This study compares lanthanum carbonate with calcium carbonate for control of serum phosphate in hemodialysis patients. Methods: In this European multicentre study, 800 patients were randomised to receive either lanthanum or calcium carbonate and the dose titrated over 5 weeks to achieve control of serum phosphate. Serum levels of phosphate, calcium and parathryoid hormone were followed over the following 20 weeks. Results: Around $65 \%$ of patients in each group achieved phosphate control, but in the calcium carbonate group this was at the expense of significant hypercalcemia $(20.2 \%$ of patients vs. $0.4 \%)$. Consequently, cal-
\end{abstract}

cium $\times$ phosphate product tended to be better controlled in the lanthanum group. Conclusion: This 6-month study demonstrates that serum phosphate control with lanthanum carbonate $(750-3,000 \mathrm{mg} / \mathrm{day})$ is similar to that seen with calcium carbonate $(1,500-9,000 \mathrm{mg} /$ day $)$, but with a significantly reduced incidence of hypercalcemia. Lanthanum carbonate is well tolerated and may be more effective in reducing calcium $\times$ phosphate product than calcium carbonate.

Copyright $\odot 2005$ S. Karger AG, Basel

\section{Introduction}

Hyperphosphatemia is an important clinical consequence of renal failure and requires concerted treatment in patients with end-stage renal disease (ESRD). Generally, normal adult serum phosphate levels range from 2.17 to $4.34 \mathrm{mg} / \mathrm{dl}(0.70-1.40 \mathrm{mmol} / \mathrm{l})$, whereas levels between 6.2 and $9.3 \mathrm{mg} / \mathrm{dl}(2.0$ and $3.0 \mathrm{mmol} / \mathrm{l})$ are frequently observed in hemodialysis patients [1]. The multiple adverse systemic effects of such high serum phosphate levels are associated with significantly increased risks of morbidity and mortality [1]. For instance, recent

\section{KARGER \\ Fax +4161306 1234 E-Mail karger@karger.ch} www.karger.com (c) 2005 S. Karger AG, Basel $1660-2110 / 05 / 1001-0008 \$ 22.00 / 0$

Accessible online at: www.karger.com/nec
Dr. A.J. Hutchison

Manchester Institute of Nephrology and Transplantation

The Royal Infirmary, Oxford Road

Manchester M13 9WL (UK)

Tel. +44 161 2764488, Fax +441612768022, E-Mail alastair.hutchison@cmmc.nhs.uk 
evidence suggests that hyperphosphatemia and an elevated level of calcium $\times$ phosphate product in patients with chronic renal failure are associated with an increased risk of vascular calcification [2]. Changes in vitamin D and parathyroid hormone (PTH) levels compound the problems associated with hyperphosphatemia and lead to a spectrum of bone pathologies collectively known as renal osteodystrophy (ROD) [2, 3]. ROD is associated with substantial patient morbidity, including bone pain and skeletal deformity $[2,4,5]$.

Oral phosphate-binding agents reduce systemic absorption of dietary phosphate allowing control of serum phosphate levels. The most effective phosphate binders that are currently available are aluminum-containing compounds. Aluminum is associated with serious toxic effects, however, such as osteomalacia, encephalopathy, myopathy, hypoparathyroidism, and anemia [6-8]. Despite this, aluminum-based phosphate binders are still used in $10-30 \%$ of patients, under careful supervision, typically within very limited time frames to achieve acute control of high phosphate levels. Calcium acetate and calcium carbonate are currently used for the longterm treatment of hyperphosphatemia in most patients. Prolonged administration of calcium salts, however, can result in hypercalcemia and oversuppression of PTH, adynamic bone, and both soft-tissue and vascular calcification [2, 9-12]. Sevelamer hydrochloride is a non-aluminum, non-calcium phosphate binder that is effective in lowering serum phosphate levels and has a diminished tendency to promote hypercalcemia. Results from a recent trial also suggest that it reduces the risk of cardiovascular calcification [13]. In a number of pivotal trials, however, sevelamer has failed to reduce serum phosphate to within recommended clinical limits [13-16].

Thus, there remains a need for new non-hypercalcemic phosphate binders that effectively control phosphate balance. Moreover, hyperphosphatemia is an independent risk factor for mortality in ESRD [1, 17], and it is believed that agents with greater phosphate-binding potency and effectiveness in reducing serum phosphate may improve long-term outcomes in ESRD.

Lanthanum has undergone extensive clinical development for use as a phosphate binder. Pre-clinical and phase I trial data suggest that the carbonate salt of lanthanum (lanthanum [III] carbonate hydrate; $\mathrm{La}_{2}\left[\mathrm{CO}_{3}\right]_{3} \cdot 4 \mathrm{H}_{2} \mathrm{O}$ ) is effective in reducing dietary phosphate absorption [18]. Unpublished data indicate that in vitro phosphate binding by lanthanum is equivalent to aluminum and superior to calcium carbonate across a range of $\mathrm{pH}$ values, as seen in the upper gastrointestinal tract. Further findings from toxicity studies with lanthanum carbonate in animals demonstrate its very low toxicity at doses of up to 20 times those recommended for clinical treatment [18, 19]. A large window of safety has also been indicated in studies in which lanthanum carbonate was administered intravenously (as a soluble chloride salt), providing lanthanum exposure many thousands of times greater than levels seen with maximal human doses [18, 20]. Unpublished animal studies have also indicated minimal systemic absorption, as estimated from the extremely low bioavailability of lanthanum carbonate following oral administration $(<0.001 \%)$ [21].

Findings from phase II and phase III clinical studies have also been published, which indicate a good safety, tolerability and efficacy profile for lanthanum carbonate in the treatment of hyperphosphatemia in ESRD patients [22-24]. Following prior treatment with other phosphate binders and subsequent washout during a phase II study, lanthanum carbonate treatment in patients undergoing hemodialysis or continuous ambulatory peritoneal dialysis resulted in $70 \%$ of patients achieving the target blood phosphate levels currently set by the UK Renal Association $(\leq 5.58 \mathrm{mg} / \mathrm{dl}(1.80 \mathrm{mmol} / \mathrm{l}))[22]$.

\section{Aims}

The present phase III study was conducted in order to assess further the ability of lanthanum carbonate to control serum phosphate levels in patients undergoing dialysis and to evaluate its tolerability and safety.

\section{Methods}

\section{Inclusion Criteria}

Male and female patients aged 18 years or over who had received hemodialysis 3 times a week for at least 3 consecutive months (including patients who had previously undergone renal transplantation) were screened for entry into the study. Female patients of childbearing potential were included only if adequate contraceptive precautions were being taken. Only patients with serum phosphate levels $>5.58 \mathrm{mg} / \mathrm{dl}$ after screening and washout were randomized to receive study medication in the titration phase. Below this level, patients were considered to be controlled and did not require a phosphate binder.

\section{Exclusion Criteria}

Exclusion criteria included significant hypercalcemia (serum calcium greater than the upper limit of normal (ULN), $10.55 \mathrm{mg} / \mathrm{dl}$ ( $2.65 \mathrm{mmol} / \mathrm{l})$ ), severe hyperparathyroidism (serum PTH $>1,000$ $\mathrm{ng} / \mathrm{l}$ ) or other clinically significant abnormal laboratory values (excluding markers of renal function) at screening. Also excluded from study entry were lactating females or those with a positive screen- 


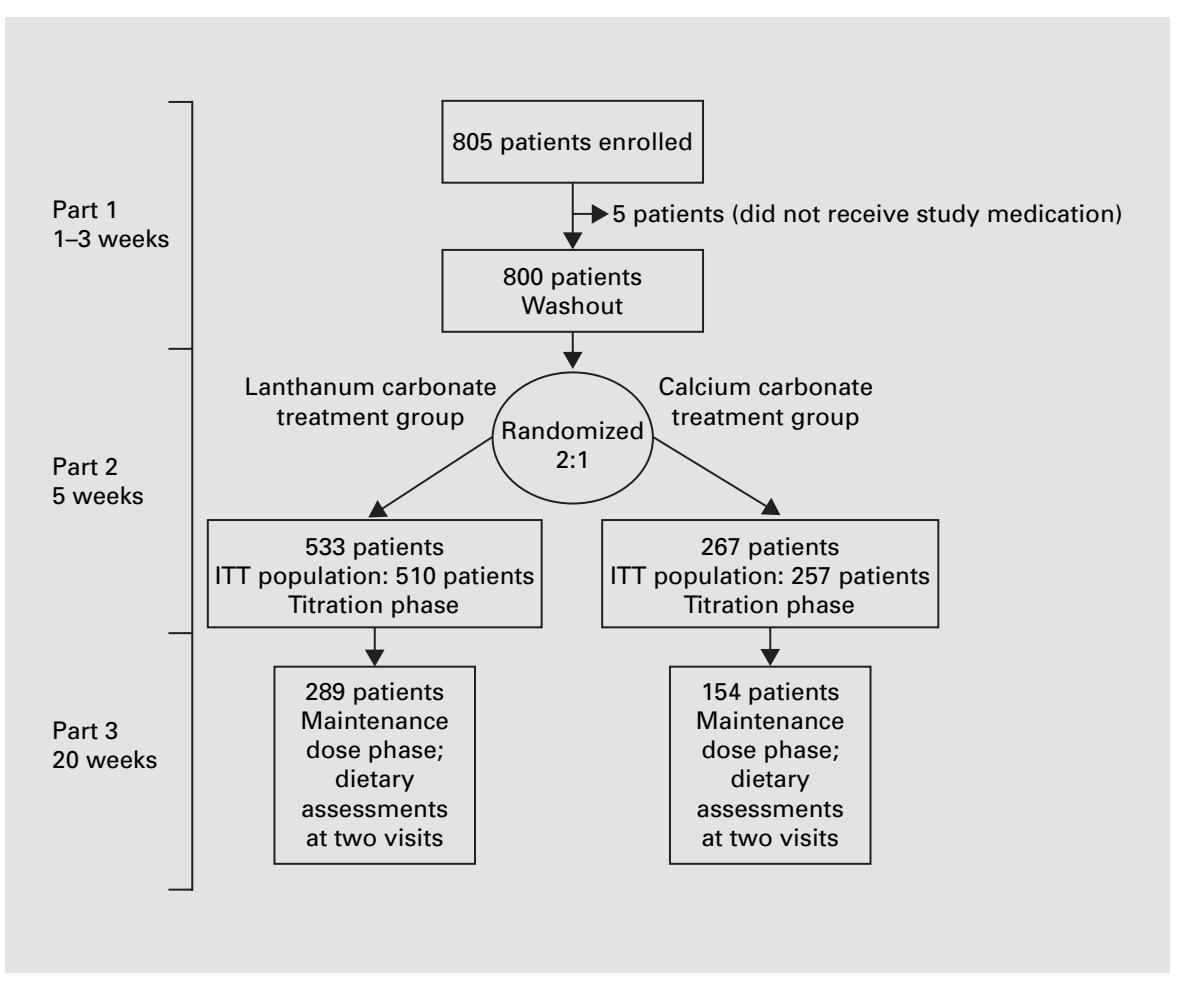

Fig. 1. Study profile.

ing pregnancy test, patients who were HIV-positive, patients with known hepatitis $\mathrm{B}$, hepatitis $\mathrm{C}$, or other significant concurrent liver disorder, and patients with a life-threatening malignancy, multiple myeloma, or a history of epilepsy. Further reasons for exclusion included a current or past history of drug or alcohol abuse within 2 years of study screening, treatment with an investigational drug 30 days prior to screening, or patients who, in the opinion of the investigator, would not comply with the study requirements.

Investigators could withdraw patients from the study if pronounced hypercalcemia (serum calcium $\geq 11.94 \mathrm{mg} / \mathrm{dl}(3.0 \mathrm{mmol} /$ 1)) occurred, or if it was thought detrimental for a patient to continue in the study. Patients could also be withdrawn from either treatment group for major protocol violation, or if their serum phosphate was not controlled after completing 5 weeks of treatment during dose titration. Patients withdrawn from the study following randomization to treatment were not replaced.

\section{Study Design}

This was a 6-month, randomized, open-label, active comparator-controlled, parallel-group trial carried out in 67 centers in the UK, Germany, Belgium, and The Netherlands. Patients were enrolled and treated between September 1998 and October 1999. The trial comprised three parts: (1) screening and washout; (2) dose titration, and (3) maintenance treatment. Study phases and timings are summarized in figure 1 .

Blood samples were taken before dialysis at the first session of each week after the longest interdialytic period. Baseline serum phosphate determinations were produced from samples taken just prior to randomization. Serum PTH and 25-hydroxyvitamin $\mathrm{D}_{3}$ levels were assessed by the central laboratory at screening and twice during treatment (following dose titration and maintenance periods). Plasma lanthanum levels were measured in blood samples taken at screening and throughout the study (at three timepoints). The lower limit of lanthanum detection in plasma in an inductive coupled plasma mass spectrometry assay (validated in conformance with US Food and Drug Administration GLPs) was $0.05 \mathrm{ng} / \mathrm{ml}$ [25]. Measurements below this limit were assigned a value of zero.

During screening and washout, patients discontinued their previous phosphate binder for a period of 1-3 weeks, during which time blood samples were taken and phosphate levels determined each week at local laboratories. Patients with serum phosphate levels $>5.58 \mathrm{mg} / \mathrm{dl}$ at the end of washout were randomized centrally to receive lanthanum carbonate, or calcium carbonate, in a ratio of $2: 1$, respectively, and entered the dose titration phase. The maximum washout period was 3 weeks, but patients reaching serum phosphate $>5.58 \mathrm{mg} / \mathrm{dl}$ sooner, after 1 or 2 weeks, were eligible for randomization. Serum phosphate levels were assessed weekly during the titration phase of treatment and the dose of phosphate binder adjusted to reduce serum phosphate to $\leq 5.58 \mathrm{mg} / \mathrm{dl}$ (defined as phosphate control).

On completion of dose titration, all patients who had achieved control of serum phosphate levels continued to receive phosphate-binder treatment for a further 20 weeks. During maintenance treatment, patients were assessed monthly, and the doses of phosphate binder were altered in order to maintain control of serum phosphate levels. Patients from either group whose serum phosphate levels did not fall to $\leq 5.58 \mathrm{mg} / \mathrm{dl}$ within the dose titration 
period of 5 weeks were not eligible to continue in the 20-week comparative maintenance phase. This was done to exclude patients who were likely to be non-compliant with their medication regimen, and to ensure that the maintenance of phosphate control was assessed only in patients showing a clear response to either calcium carbonate or lanthanum carbonate.

The study was conducted according to ICH Guidelines for Good Practice. The protocol was approved by independent ethics committees at each study site and conformed to the principles outlined by the Helsinki Declaration and all subsequent revisions at the time of study initiation. All patients entering the study provided written, informed consent.

\section{Drug Dosage}

Each week, medication was dispensed after pre-dialysis serum phosphate levels had been evaluated. Lanthanum carbonate was supplied as unflavored, round, chewable tablets containing either 125 or $250 \mathrm{mg}$ of elemental lanthanum. Calcium carbonate was supplied as round, chewable, orange-flavored tablets containing $500 \mathrm{mg}$ of elemental calcium. Initial daily doses for patients randomized to lanthanum carbonate and calcium carbonate treatment contained $375 \mathrm{mg} /$ day of lanthanum and 1,500 mg/day of calcium. If phosphate levels fell to $<3.1 \mathrm{mg} / \mathrm{dl}(1.00 \mathrm{mmol} / \mathrm{l})$ after the starting dose with either agent, the total daily dose was reduced to provide $250 \mathrm{mg} /$ day of lanthanum or $1,000 \mathrm{mg} /$ day of calcium. Throughout subsequent dose titration, lanthanum carbonate was provided to supply elemental lanthanum doses of 375, 750, 1,500, 2,250 , or $3,000 \mathrm{mg} / \mathrm{day}$. Doses of calcium carbonate provided $1,500,3,000,4,500,6,000$, or $9,000 \mathrm{mg} /$ day of elemental calcium.

All phosphate-binder medication was given in three divided doses with meals. Patients receiving lanthanum carbonate took their medication immediately after meals. Those receiving calcium carbonate took their medication just before each meal, in accordance with the product information sheet. Drug doses could be titrated either up or down by altering the number of tablets administered.

Phosphate binders are required to remove an average of around $400 \mathrm{mg}$ of dietary phosphate/day. Stoichiometric calculations, in vitro binding experiments, and studies using isolated rat gut models, suggest that lanthanum carbonate doses providing 1,000 mg of elemental lanthanum per day can achieve this. With this knowledge, the range of doses of lanthanum carbonate was chosen on the basis of evidence from pre-clinical toxicology studies, in which oral doses of up to $2,000 \mathrm{mg} / \mathrm{kg} /$ day showed a good safety profile in animals, and from phase II clinical trials, which demonstrated good efficacy and tolerability at doses of up to $2,250 \mathrm{mg} /$ day and indicated that a maximum dose of $3,000 \mathrm{mg} /$ day may be required [ 22 , 24]. Doses of calcium carbonate were chosen on the basis of those used in routine clinical practice.

\section{Concomitant Medications}

Phosphate binders other than the study medications were excluded following screening until withdrawal or completion of the study. Patients taking drugs with the potential to interact with antacids (including tetracyclines, some cephalosporins, itraconazole, ketoconazole, chloroquine, hydroxychloroquine, phenothiazines, phenytoin, and penicillamine) were instructed to take them at least $2 \mathrm{~h}$ after dosing with lanthanum carbonate. Patients were advised not to take over-the-counter products containing aluminum (including sucralfate), phosphates, or magnesium, during the study.
Vitamin D use was initially restricted to avoid confounding changes in phosphate levels resulting from treatment. Patients receiving vitamin $\mathrm{D}$ on entry to the study were therefore required to remain on the same dose of vitamin D until the end of week 18. Patients not receiving vitamin $\mathrm{D}$ on study entry could not be initiated on vitamin D until this time. After week 18, vitamin D could be used as required. Investigators were permitted to alter the concentration of calcium in dialysis fluid as required.

\section{Assessments}

Reduction of serum phosphate to $\leq 5.58 \mathrm{mg} / \mathrm{dl}$ was the primary efficacy endpoint. Patients in whom the target reduction was reached were considered to have achieved phosphate control. Secondary efficacy endpoints included the maintenance of serum phosphate control at $\leq 5.58 \mathrm{mg} / \mathrm{dl}$ (assessed by the proportion of patients with controlled serum phosphate), determination of the level of lanthanum in serum, and assessment of the tolerability and safety of lanthanum carbonate. Calcium $\times$ phosphate product was also calculated (at screening, and throughout titration and maintenance treatment).

Assessments of tolerability and safety included adverse-event monitoring, physical examination, measurement of vital signs, and routine laboratory measurements. In particular, all treatmentemergent adverse events (i.e. any adverse event occurring after at least one dose of study medication) were recorded. Hypercalcemia was defined as a level greater than the ULN as specified by the central laboratory.

\section{Dietary Assessment}

Dietary assessments were performed in a subgroup of patients $(\mathrm{n}=95)$ at two time-points during maintenance treatment, to assess if reductions in serum phosphate levels were as a result of the study treatments and were not influenced by changes in dietary intake of phosphate, calcium, protein, vitamin $\mathrm{D}$, and kilocalories.

\section{Statistics}

Calculations to determine sample size, assumed a 95\% level of significance (two-tailed), 90\% power, and a similar withdrawal rate in the two treatment groups. In total, 585 patients (390 receiving lanthanum carbonate and 195 receiving calcium carbonate) were required to detect a $10 \%$ difference in the proportion of phosphatecontrolled patients between treatments (odds ratio 2.25).

Primary efficacy, tolerability, and safety analyses were based on the intention-to-treat (ITT) population, defined as all patients who were randomized to treatment, who received at least one dose of medication and for whom evaluable data were available. A population intended for safety analysis was defined as all patients who were randomized and who received at least one dose of study medication.

All data analysis and reporting were performed using SAS software (version 6.12). Nominal or binary data (e.g. proportion of patients with controlled phosphate) were analyzed by the $\chi^{2}$ or Fisher's exact test. Ordered categorical data, such as the frequency of dose adjustments or uncontrolled phosphate reports, were analyzed using the Cochran-Mantel-Haenszel test with integer scores. Continuous, normally distributed data were analyzed by analysis of variance (ANOVA) or covariance (ANCOVA). 


\section{Results}

\section{Patient Disposition}

Patient disposition throughout the study is summarized in figure 1. In total, 1,013 patients were screened for entry into the trial. A total of 800 patients completed the 3 -week screening and washout phase and were randomized to receive study medication. Of these, 533 patients receiving lanthanum carbonate, and 267 patients receiving calcium carbonate, received at least one dose of study medication and were included in the ITT safety analysis population. Efficacy data for 33 of these patients (all from a single center) were not included in the final data analysis because of the unreliability of data generated at this center. Thus, the ITT efficacy analysis population comprised 767 patients, 510 treated with lanthanum carbonate and 257 treated with calcium carbonate.

Of the 533 patients who commenced titration with lanthanum carbonate, 289 (54.2\%) completed both titration and maintenance treatment over a total of 24 weeks. Of the 267 patients receiving calcium carbonate treatment, 154 (57.7\%) progressed to and completed maintenance treatment.

\section{Demographic and Other Baseline Characteristics}

Baseline characteristics of the ITT patient population were similar in the lanthanum carbonate and calcium carbonate treatment groups in terms of age, gender, body weight, race, medical histories, characteristics of renal disease, and concomitant use of medications (table 1). The primary and secondary diagnoses were also similarly distributed in the two groups, with the most common diagnosis being glomerulonephritis $(29.6 \%$ of the lanthanum carbonate group and $25.3 \%$ of the calcium carbonate group). The use of concomitant medications was well balanced between the two groups throughout the study.

\section{Drug Treatment}

The distributions of phosphate-binder doses administered between the end of dose titration and the end of maintenance treatment are summarized in figure 2 . Smaller doses of elemental lanthanum than elemental calcium were required to maintain similar degrees of serum phosphate control in the two treatment arms. Overall, the most frequently administered doses contained $1,500 \mathrm{mg}$ of lanthanum and 3,000 $\mathrm{mg}$ of calcium. In terms of pill count, the number of pills that patients were required to take was also lower in the lanthanum carbonate group. Approximately $73 \%$ of patients took $\leq 9$ pills of lanthanum carbonate per day, compared with $61 \%$ of patients
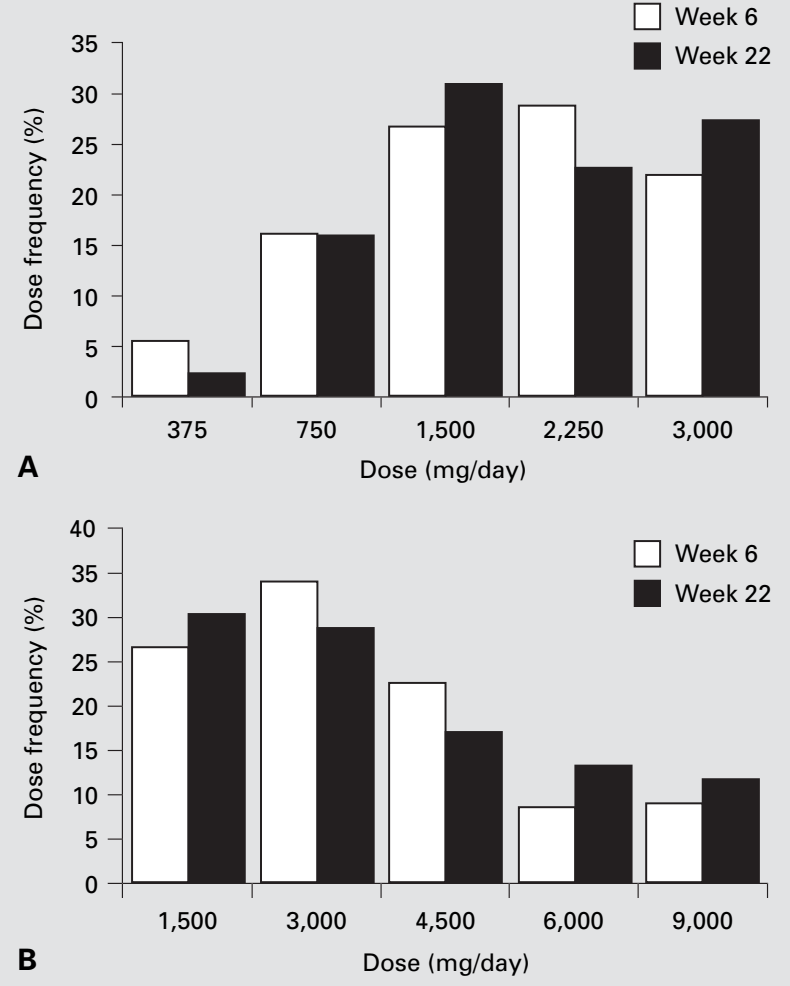

Fig. 2. Frequency of doses of lanthanum (A) (as lanthanum carbonate) and calcium (B) (as calcium carbonate) during titration (week 6) and maintenance treatment (week 22) in the ITT population.

Table 1. Demographic and other baseline characteristics

\begin{tabular}{|c|c|c|}
\hline \multirow{2}{*}{ Characteristic } & \multicolumn{2}{|c|}{ Treatment group } \\
\hline & $\begin{array}{l}\text { lanthanum } \\
\text { carbonate } \\
(\mathrm{n}=510)\end{array}$ & $\begin{array}{l}\text { calcium } \\
\text { carbonate } \\
(\mathrm{n}=257)\end{array}$ \\
\hline \multicolumn{3}{|l|}{ Age, years } \\
\hline Mean (SD) & $57.0(14.3)$ & $58.4(13.38)$ \\
\hline Range & $19-87$ & $21-85$ \\
\hline Male gender, n (\%) & $341(66.9)$ & $164(63.8)$ \\
\hline \multicolumn{3}{|l|}{ Body weight, $\mathrm{kg}$} \\
\hline Mean (SD) & $75.1(15.4)$ & $73.7(14.9)$ \\
\hline Range & $40.4-153.4$ & $37.6-138.0$ \\
\hline \multicolumn{3}{|l|}{ Renal disease characteristics } \\
\hline Months on hemodialysis, mean (SD) & $42.9(39.0)$ & $43.8(43.9)$ \\
\hline $\begin{array}{l}\text { Patients with residual renal } \\
\text { function, } \mathrm{n}(\%)\end{array}$ & $300(62.0)$ & $154(63.6)$ \\
\hline $\begin{array}{l}\text { Patients with previous kidney } \\
\text { transplant, } \mathrm{n}(\%)\end{array}$ & $63(12.4)$ & $33(12.8)$ \\
\hline
\end{tabular}




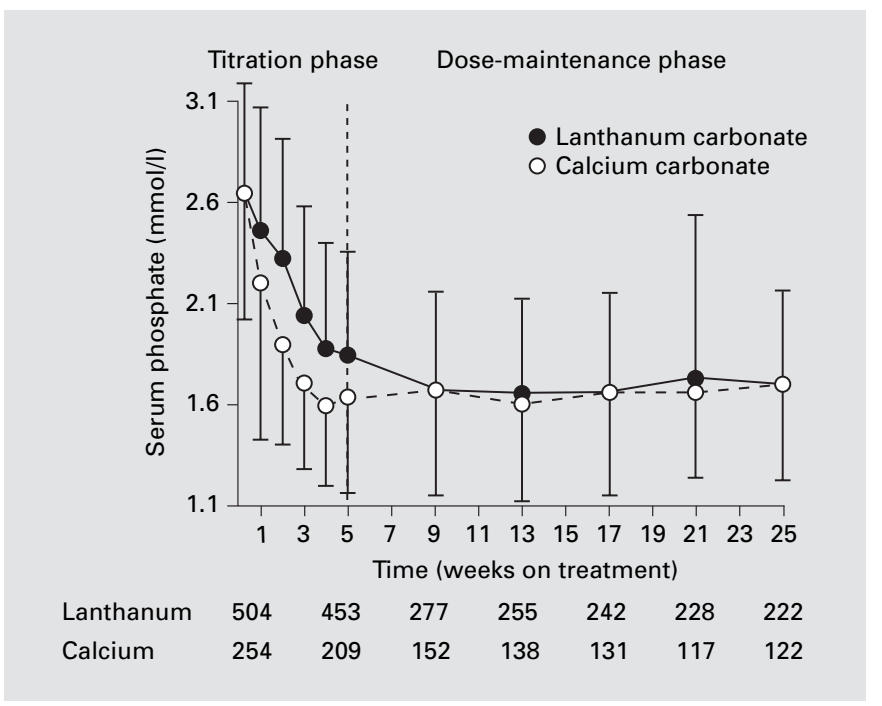

Fig. 3. Mean serum phosphate levels during titration and maintenance treatment in the ITT population.

Table 2. Proportions of phosphate-controlled patients during maintenance treatment (ITT)

\begin{tabular}{|c|c|c|c|c|c|}
\hline \multirow{3}{*}{$\begin{array}{l}\text { Weeks on } \\
\text { treatment }\end{array}$} & \multicolumn{4}{|c|}{ Treatment group } & \multirow{3}{*}{$\begin{array}{l}\mathrm{p} \text { value } \\
\left(\chi^{2} \text { test }\right)\end{array}$} \\
\hline & \multicolumn{2}{|c|}{$\begin{array}{l}\text { lanthanum carbonate } \\
(\mathrm{n}=277)\end{array}$} & \multicolumn{2}{|c|}{$\begin{array}{l}\text { calcium carbonate } \\
(\mathrm{n}=152)\end{array}$} & \\
\hline & $\mathrm{n}$ & $\%$ & $\mathrm{n}$ & $\%$ & \\
\hline 9 & $188 / 277$ & 67.9 & $100 / 152$ & 65.8 & 0.66 \\
\hline 13 & $179 / 255$ & 70.2 & $104 / 138$ & 75.4 & 0.28 \\
\hline 17 & $166 / 242$ & 68.6 & $90 / 131$ & 68.7 & 0.98 \\
\hline 21 & $158 / 228$ & 69.3 & $85 / 117$ & 72.6 & 0.52 \\
\hline 25 & $146 / 222$ & 65.8 & $78 / 122$ & 63.9 & 0.73 \\
\hline
\end{tabular}

taking calcium carbonate. Moreover, $11 \%$ of patients took 18 calcium carbonate tablets per day, whereas the top dose of lanthanum carbonate required to achieve similar overall phosphate control amounted to 12 tablets (taken by $27 \%$ of patients). Residual renal function (measured as production of urine), age and patient body weight did not have any notable effect on required dosage levels with either drug.

\section{Efficacy}

Dose Titration. Serum phosphate levels in the ITT population of lanthanum carbonate- and calcium carbonate-treated patients throughout the 6-month treatment period are shown in figure 3. Similar mean $( \pm$ SD) serum phosphate levels were seen in lanthanum carbonate- and calcium carbonate-treated patients at baseline $(8.28 \pm$ $2.05 \mathrm{mg} / \mathrm{dl}(2.67 \pm 0.66 \mathrm{mmol} / \mathrm{l})$ and $8.34 \pm 1.95 \mathrm{mg} / \mathrm{dl}$ $(2.69 \pm 0.63 \mathrm{mmol} / \mathrm{l})$, respectively). At the end of 5 weeks of dose titration, these values had decreased to $5.79 \pm$ $1.61 \mathrm{mg} / \mathrm{dl}(1.87 \pm 0.52 \mathrm{mmol} / \mathrm{l})$ in the lanthanum carbonate group and $5.15 \pm 1.49 \mathrm{mg} / \mathrm{dl}(1.66 \pm 0.48 \mathrm{mmol} /$ 1) in the calcium carbonate group (fig. 3 ).

Analysis of the proportions of patients with controlled versus uncontrolled serum phosphate levels during dose titration showed a relative time lag to achievement of control in the lanthanum carbonate group, compared with the calcium carbonate group. After 1 week of dose titration, the phosphate levels were controlled in $12.4 \%$ of lanthanum carbonate-treated patients and $23.7 \%$ of calcium carbonate-treated patients. At the end of 5 weeks of dose titration, the percentages of phosphate-controlled patients in the lanthanum carbonate and calcium carbonate groups were 57.8 and $70.3 \%$, respectively (treatment difference, $p=0.002$ ).

Maintenance Treatment. The reductions in mean serum phosphate levels to $<5.58 \mathrm{mg} / \mathrm{dl}$ achieved within the dose titration phase were sustained for the duration of maintenance treatment (at weeks 9 and 25, respectively) both in lanthanum carbonate- and calcium carbonatetreated patients (table 2). Generally, the proportions of patients in whom control of serum phosphate was achieved were similar between the two treatment groups during the maintenance phase. After 9 weeks of treatment with lanthanum carbonate, $67.9 \%$ of patients showed controlled serum phosphate levels, compared with $65.8 \%$ of patients in the calcium carbonate group. Similar proportions of patients achieved phosphate control after 25 weeks of treatment (65.8 and $63.9 \%$ in the lanthanum carbonate, and calcium carbonate groups, respectively; table 2). Differences between the treatment groups were not significant (treatment difference, $p>0.05$ at all time-points).

Dietary assessments throughout the study discounted any confounding effects of dietary phosphate intake on these efficacy results in either the lanthanum carbonate or calcium carbonate groups. Patients' diets remained consistent throughout the study. In addition, there were no clinically important differences between the treatment groups in the intake of phosphate, calcium, protein, vitamin $\mathrm{D}$, and kilocalories, with or without correction for body weight.

Calcium $\times$ Phosphate Product. Reductions in calcium $\times$ phosphate product were generally greater with lantha- 
Table 3. Mean (SD) values and mean (SD) changes from baseline in calcium $\times$ phosphate product during titration and maintenance treatment (ITT)

\begin{tabular}{|c|c|c|c|c|c|c|c|}
\hline \multirow[t]{2}{*}{ Phase } & \multirow[t]{2}{*}{ Parameter } & \multicolumn{6}{|c|}{ Calcium $\times$ phosphate product $\left(\mathrm{mmol}^{2} / \mathrm{l}^{2}\right)$ change from baseline } \\
\hline & & $\mathrm{n}$ & $\begin{array}{l}\text { lanthanum } \\
\text { carbonate } \\
(\mathrm{n}=510)\end{array}$ & $\mathrm{n}$ & $\begin{array}{l}\text { calcium } \\
\text { carbonate } \\
(\mathrm{n}=257)\end{array}$ & $\begin{array}{l}\text { difference } \\
\text { between } \\
\text { treatments }\end{array}$ & $\mathrm{p}$ value $* \dagger$ \\
\hline \multicolumn{8}{|l|}{ Titration } \\
\hline \multirow[t]{2}{*}{ Week 5} & Value & 447 & $4.36(1.27)$ & 207 & $4.20(1.23)$ & & \\
\hline & Mean change & & $-1.67(1.75)$ & & $-1.68(1.63)$ & 0.01 & 0.961 \\
\hline \multicolumn{8}{|c|}{ Maintenance } \\
\hline \multirow[t]{2}{*}{ Week 17} & Value & 239 & $3.81(1.14)$ & 130 & $4.07(1.20)$ & & \\
\hline & Mean change & & $-1.80(1.65)$ & & $-1.35(1.51)$ & -0.45 & 0.009 \\
\hline \multirow[t]{2}{*}{ Week 25} & Value & 220 & $4.01(1.11)$ & 121 & $4.19(1.14)$ & & \\
\hline & Mean change & & $-1.59(1.70)$ & & $-1.26(1.25)$ & -0.33 & 0.061 \\
\hline
\end{tabular}

*Mean change and †absolute value differences assessed by ANOVA. To convert from $\mathrm{mmol}^{2} / \mathrm{l}^{2}$ to $\mathrm{mg}^{2} / \mathrm{dl}^{2}$, multiply values by 12.38 .

Table 4. Serum PTH (ng/l), 25-hydroxyvitamin $\mathrm{D}_{3}(\mathrm{ng} / \mathrm{ml})$ and calcium $(\mathrm{mmol} / \mathrm{l})$ levels at screening and at the end of each treatment period (weeks 6 and 26 in the safety population)

\begin{tabular}{|c|c|c|c|c|c|c|}
\hline & \multicolumn{3}{|c|}{ Lanthanum carbonate } & \multicolumn{3}{|c|}{ Calcium carbonate } \\
\hline & screening & $\begin{array}{l}\text { end of } \\
\text { titration }\end{array}$ & $\begin{array}{l}\text { end of } \\
\text { maintenance }\end{array}$ & screening & $\begin{array}{l}\text { end of } \\
\text { titration }\end{array}$ & $\begin{array}{l}\text { end of } \\
\text { maintenance }\end{array}$ \\
\hline \multicolumn{7}{|l|}{ PTH } \\
\hline $\mathrm{n}$ & 507 & 449 & 226 & 255 & 203 & 114 \\
\hline Median & 127 & 174 & 166 & 163 & 98 & 114 \\
\hline Range & $0.00-2,018$ & $2.00-2,040$ & $3.00-1,250$ & $0.00-1,478$ & $0.00-1,203$ & $6.00-1,560$ \\
\hline \multicolumn{7}{|c|}{ 25-Hydroxyvitamin $D_{3}$} \\
\hline $\mathrm{n}$ & 508 & 450 & 226 & 256 & 203 & 115 \\
\hline Median & 43.7 & 37.4 & 57.4 & 37.4 & 30.0 & 47.4 \\
\hline Range & $0.00-230$ & $7.49-300$ & $7.49-202$ & $0.00-250$ & $7.49-162$ & $7.49-175$ \\
\hline \multicolumn{7}{|l|}{ Calcium $^{1}$} \\
\hline $\mathrm{n}$ & 527 & 467 & 235 & 264 & 213 & 124 \\
\hline Mean $\pm \mathrm{SD}$ & $0.57 \pm 0.05$ & $0.58 \pm 0.06$ & $0.58 \pm 0.01$ & $0.56 \pm 0.07$ & $0.63 \pm 0.08$ & $0.61 \pm 0.07$ \\
\hline Range & $0.29-0.70$ & $0.14-0.73$ & $0.44-0.70$ & $0.23-0.70$ & $0.34-1.00$ & $0.46-0.79$ \\
\hline
\end{tabular}

${ }^{1}$ Values in $\mathrm{mg} / \mathrm{dl}$ can be obtained by multiplying by 4.0 .

num carbonate maintenance treatment than with calcium carbonate (table 3). After 17 weeks of treatment, lanthanum carbonate was associated with a significantly greater decrease in calcium $\times$ phosphate product, compared with calcium carbonate $(\mathrm{p}=0.009)$. A trend towards reduced calcium $\times$ phosphate product was maintained at 25 weeks $(p=0.061)$.
Serum PTH and vitamin D. At the screening visit, the median PTH values in the lanthanum carbonate and calcium carbonate groups were 127 and 163 ng/l, respectively. PTH levels at the end of titration had increased to $174 \mathrm{ng} / \mathrm{l}$ with lanthanum carbonate (+47 ng/l vs. screening) and decreased to $98 \mathrm{ng} / \mathrm{l}$ with calcium carbonate (-65 ng/l vs. screening). By the end of the maintenance 
Table 5. Percentage (number) of patients reporting treatment-emergent adverse events and serious adverse events during titration and maintenance treatment at a frequency $\geq 5 \%$ (safety population)

\begin{tabular}{|c|c|c|c|}
\hline \multirow[t]{2}{*}{ Body system } & \multirow[t]{2}{*}{ WHO-preferred term } & \multicolumn{2}{|c|}{ Treatment group } \\
\hline & & $\begin{array}{l}\text { lanthanum } \\
\text { carbonate } \\
(\mathrm{n}=533)\end{array}$ & $\begin{array}{l}\text { calcium } \\
\text { carbonate } \\
(\mathrm{n}=267)\end{array}$ \\
\hline \multicolumn{4}{|l|}{ Adverse events } \\
\hline Cardiovascular disorders & Hypotension $^{1}$ & $7.5(40)$ & $9.0(24)$ \\
\hline Central and peripheral nervous system disorders & Headache & $5.1(27)$ & $6.4(17)$ \\
\hline Dialysis complication & Dialysis graft occlusion & $4.1(22)$ & $6.4(17)$ \\
\hline \multirow[t]{4}{*}{ Gastrointestinal system disorders } & Constipation & $6.0(32)$ & $6.7(18)$ \\
\hline & Diarrhea & $12.6(67)$ & $9.7(26)$ \\
\hline & Nausea & $15.9(85)$ & $12.7(34)$ \\
\hline & Vomiting & $18.4(98)$ & $11.2(30)$ \\
\hline Metabolic and nutritional disorders & Hypercalcemia & $0.4(2)$ & $20.2(54)$ \\
\hline Musculoskeletal system disorders & Cramps & $7.1(38)$ & $6.4(17)$ \\
\hline \multirow[t]{2}{*}{ Respiratory system disorders } & Bronchitis & $4.7(25)$ & $5.6(15)$ \\
\hline & Rhinitis & $6.9(37)$ & $6.0(16)$ \\
\hline \multicolumn{4}{|l|}{ Serious adverse events } \\
\hline \multirow[t]{2}{*}{ Dialysis complication } & Catheter complication & $1.1(6)$ & $0.7(2)$ \\
\hline & Graft occlusion & $3.8(20)$ & $5.2(14)$ \\
\hline Myo-, endo-, pericardial and valve disorders & Angina pectoris & $1.1(6)$ & $0.4(1)$ \\
\hline Resistance mechanism disorders & Sepsis & $0(0)$ & $1.1(3)$ \\
\hline Secondary terms - events & Surgical intervention & $1.1(6)$ & $0.7(2)$ \\
\hline Urinary system disorders & Renal transplant & $2.4(13)$ & $4.1(11)$ \\
\hline Vision disorders & Cataract & $0.4(2)$ & $1.1(3)$ \\
\hline Total patients reporting $\geq 1$ adverse event & & $77.7(414)$ & $79.8(213)$ \\
\hline Total number of adverse events & & 1,596 & 827 \\
\hline
\end{tabular}

WHO = World Health Organization.

${ }^{1}$ Measured during dialysis.

phase, the median serum PTH levels were $166 \mathrm{ng} / \mathrm{l}$ in the lanthanum carbonate group and $114 \mathrm{ng} / \mathrm{l}$ in the calcium carbonate group (table 4). Very few investigators made changes to vitamin D therapy after week 18 (lanthanum group: $n=26$; calcium group: $n=6$ ). At the end of the maintenance phase, median PTH levels in these patients were higher than levels in those who had no change in their vitamin D use (lanthanum group: 290 vs. $167 \mathrm{ng} / \mathrm{l}$; calcium group: 218 vs. $116 \mathrm{ng} / \mathrm{l})$. Serum levels of 25-hydroxyvitamin $\mathrm{D}_{3}$ at the end of each treatment phase are shown in table 4.

\section{Tolerability and Safety}

Hypercalcemia. The most notable difference between the tolerability and safety profiles of lanthanum carbonate and calcium carbonate was the frequency of clinically significant hypercalcemia reported as an adverse event. Overall, hypercalcemia occurred in $0.4 \%$ of patients treated with lanthanum carbonate, compared with $20.2 \%$ of patients treated with calcium carbonate.

Mean serum calcium levels remained unchanged or marginally decreased in the lanthanum carbonate group. The mean screening value was $9.47 \pm 0.92 \mathrm{mg} / \mathrm{dl}(2.38$ $\pm 0.23 \mathrm{mmol} / \mathrm{l})$, and changes from this value by the end of titration were between -0.04 and $-0.79 \mathrm{mg} / \mathrm{dl}(-0.01$ and $-0.20 \mathrm{mmol} / \mathrm{l}$ ) across all dose levels. During maintenance treatment, changes ranged between -0.16 and $-0.99 \mathrm{mg} / \mathrm{dl}(-0.04$ and $-0.25 \mathrm{mmol} / \mathrm{l})$. In calcium carbonate-treated patients, mean serum calcium was consistently increased. The mean screening value was $9.35 \pm$ $0.96 \mathrm{mg} / \mathrm{dl}(2.35 \pm 0.24 \mathrm{mmol} / \mathrm{l})$ and mean changes from screening ranged between +0.12 and $+0.92 \mathrm{mg} / \mathrm{dl}(+0.03$ and $+0.23 \mathrm{mmol} / \mathrm{l}$ ) at the end of titration across all doses. During maintenance treatment, changes ranged between +0.12 and $+0.60 \mathrm{mg} / \mathrm{dl}(+0.03$ and $+0.15 \mathrm{mmol} / \mathrm{l})$. 
In total, only $6 \%$ of lanthanum carbonate-treated patients experienced hypercalcemic episodes (defined as any occurrence of serum calcium values above the ULN range), compared with $38 \%$ of patients in the calcium carbonate group. Of those who did experience hypercalcemic episodes with calcium carbonate, two or more episodes occurred in 38 patients, and four or more episodes were observed in 10 patients. Only 13 patients in the lanthanum carbonate group experienced more than one episode; four or more episodes occurred in 4 patients. Overall, the greater frequency of hypercalcemic episodes with calcium carbonate represented a statistically significant treatment difference $(\mathrm{p}<0.001)$.

Adverse Events. The incidences of treatment-emergent adverse events (i.e. any adverse event occurring after administration of at least one dose of study medication) reported during dose titration and maintenance treatment were $77.7 \%$ in patients treated with lanthanum carbonate and $79.8 \%$ in those treated with calcium carbonate. Numbers and proportions of patients reporting adverse events at a frequency $\geq 5 \%$ in the two treatment groups during all three phases of the study are shown in table 5. Most adverse events were of mild or moderate severity in both lanthanum carbonate- and calcium carbonate-treated patients during the titration and maintenance phases; $<10 \%$ of adverse events were classified as severe.

Gastrointestinal adverse events were reported most frequently and occurred with similar frequency in the two treatment groups. Overall, no gastrointestinal adverse events were serious, and incidence rates were of the same order of magnitude with lanthanum carbonate and calcium carbonate. Constipation occurred in $0.7 \%$ more patients treated with calcium carbonate than with lanthanum carbonate. Diarrhea and nausea appeared in around $3 \%$ more patients treated with lanthanum carbonate than with calcium carbonate. The largest difference in adverseevent incidence between the two groups was seen for vomiting ( $7 \%$ more frequent with lanthanum carbonate). Other adverse events occurring with $\geq 5 \%$ frequency in both treatment groups included cardiovascular, nervous system, musculoskeletal, respiratory system disorders, and vascular access complications.

During dose titration and maintenance treatment, 21.4 and $30.0 \%$ of patients reported serious adverse events in the lanthanum carbonate and calcium carbonate groups, respectively. The frequency and type of serious adverse events in both treatment groups were typical for patients with chronic renal failure undergoing hemodialysis (table 5) and none were considered by the inves- tigators to be related to treatment with lanthanum carbonate. The investigators considered that two serious adverse events (both hypercalcemia), however, were related to calcium carbonate treatment. Overall, the majority (around 70\%) of serious adverse events were of mild or moderate severity in both treatment groups.

Laboratory Investigations. Changes in laboratory parameters between baseline and the end of maintenance treatment (week 25) were similar in lanthanum carbonate- and calcium carbonate-treated patients. Hematology and biochemistry results from full laboratory screens showed only minor changes between baseline and week 25 , with little difference between the two treatments. No consistent pattern of change over time was recorded for most parameters. Notably, mean serum bicarbonate levels increased from a screening value of 17.9 to 19.5 $\mathrm{mEq} / \mathrm{l}$ by the end of maintenance treatment with lanthanum carbonate and from 17.9 to $20.0 \mathrm{mEq} / \mathrm{l}$ with calcium carbonate, indicating a beneficial (non-significant) trend towards normal values (currently recommended as $22 \mathrm{mEq} / \mathrm{l}$ ) with both treatments. No changes were seen in measurements of vital signs either between the treatment groups or over time in either treatment group.

Plasma lanthanum levels were generally very low during lanthanum carbonate treatment of up to 6 months. The mean screening value of plasma lanthanum was 0.01 $\pm 0.06 \mathrm{ng} / \mathrm{ml}$ in the lanthanum carbonate group. At the top dosing level (3,000 $\mathrm{mg} /$ day of elemental lanthanum), plasma lanthanum concentrations were $0.55 \pm 0.53 \mathrm{ng} /$ $\mathrm{ml}$ at the end of titration and $0.49 \pm 0.39 \mathrm{ng} / \mathrm{ml}$ at the end of 5 months of maintenance treatment. These levels represent around 0.5 parts per billion of the top dose administered; changes from screening were not statistically significant at any dose level. A minimal increase in plasma lanthanum concentration with dose was observed, but this was not sufficient to qualify as a dose-related effect.

Corresponding (background) plasma lanthanum levels in patients receiving calcium carbonate ranged between $0.01 \pm 0.02$ and $0.03 \pm 0.04 \mathrm{ng} / \mathrm{ml}$ at the end of titration and between $0.00 \mathrm{ng} / \mathrm{ml}$ and $0.01 \mathrm{ng} / \mathrm{ml}$ at the end of maintenance treatment, though lanthanum levels as high as $0.60 \mathrm{ng} / \mathrm{ml}$ were detected in individual patients.

\section{Discussion}

Overall, the efficacy findings presented here suggest that lanthanum carbonate is as effective as calcium carbonate in controlling serum phosphate. Responses to the two agents were marginally different during dose titration 
because of a suboptimal starting dose of lanthanum carbonate $(375 \mathrm{mg})$. Analysis of the response curves of the two treatments in the present study (fig. 3) suggests that initiation of lanthanum carbonate at $750 \mathrm{mg} /$ day would have resulted in phosphate control being achieved earlier in the lanthanum carbonate group. In addition, the starting dose of calcium carbonate $(1,500 \mathrm{mg} /$ day $)$ was probably higher than normally initiated in clinical practice, where a dose of $1,000 \mathrm{mg} /$ day is perhaps more commonly used.

Following dose titration, satisfactory control of serum phosphate levels was continued throughout maintenance treatment up to week 25 (endpoint) in both treatment groups. As the study was designed with a target serum phosphate level of $5.58 \mathrm{mg} / \mathrm{dl}(1.80 \mathrm{mmol} / \mathrm{l})$ and an upper dosage limit of 3,000 mg/day for lanthanum carbonate, it was considered likely that mean serum phosphate levels would be similar in the two groups during maintenance treatment (fig. 3). Mean serum phosphate concentrations were $5.24 \mathrm{mg} / \mathrm{dl}(1.69 \mathrm{mmol} / \mathrm{l})$ in both treatment groups at study endpoint. Likewise, the proportions of phosphate-controlled patients remained equivalent between the two treatment groups throughout and up to the end of maintenance treatment (66\% in the lanthanum carbonate group and $64 \%$ in the calcium carbonate group). It should be noted, however, that the role of dialysis dose, session duration, membrane type and dialytic modality in phosphate removal was not assessed during the study.

The substantially higher frequency of hypercalcemia reported as an 'adverse event' in the calcium carbonate group (20.2\%), compared with the lanthanum carbonate group $(0.4 \%)$, was striking, although not surprising given the high doses of calcium carbonate that were necessary to reduce serum phosphate to the target level in this study. This was reflected by the significantly higher incidence of hypercalcemic episodes (serum calcium $>$ ULN) in the calcium carbonate group than in the lanthanum carbonate group ( 38 vs. $6 \%$, respectively). Patients treated with lanthanum carbonate also showed a greater reduction from baseline in calcium $\times$ phosphate product during maintenance treatment than calcium carbonate-treated patients. These results should be interpreted with caution, as investigators were free to alter the concentration of serum dialysate as necessary, while changes in vitamin D therapy were restricted until week 18 of the study. As an association has been observed between calcium intake and vascular calcification $[9,13,26]$, however, it appears that lanthanum carbonate may offer a potential advantage over calcium-based phosphate binders in this regard.

Lanthanum Carbonate in

Hyperphosphatemia
The importance of PTH in calcium-phosphate homeostasis and the possible role of PTH as a risk factor in cardiovascular calcification require that PTH status be adequately monitored and effectively controlled in patients with ESRD [27]. It is difficult, however, to assess how the changes in serum PTH seen in this study reflect what would be observed during normal clinical use. Changes in median PTH levels during titration suggest that PTH is more likely to rise during lanthanum carbonate treatment than during calcium carbonate treatment. In clinical practice, however, rising PTH levels would be treated using oral vitamin $\mathrm{D}_{3}$. In this study, vitamin $\mathrm{D}$ use was restricted up to week 18 and very few investigators made adjustments in vitamin $\mathrm{D}$ therapy after this time-point. It is not possible to assess the potential benefit of controlling PTH concomitantly with serum phosphate from these study results. One previous large-scale study by Joy et al. [23] allowed a realistic assessment of PTH changes during lanthanum carbonate treatment, albeit over a shorter time period. In their analysis they found that PTH levels changed by $<3 \%$ with lanthanum carbonate treatment during a 4-week, placebo-controlled maintenance period.

During the tolerability and safety analysis, adverseevent monitoring showed that lanthanum carbonate was well tolerated. There were no clinically important differences between the lanthanum carbonate and calcium carbonate groups in the incidence of most individual (e.g. gastrointestinal) adverse events. Apart from hypercalcemia (reported as an adverse event), the only difference between the treatment groups in the incidence of adverse events occurring with $\geq 5 \%$ frequency was for vomiting, which occurred in $18.4 \%$ of patients receiving lanthanum carbonate, and $11.2 \%$ of patients receiving calcium carbonate. It is possible that this is the result of patients taking lanthanum before food, rather than after food as advised, perhaps having become accustomed to taking their previous phosphate-binding medication before meals.

Plasma lanthanum levels observed in this study were very low, reflecting the extremely low levels of systemic exposure to lanthanum reported in unpublished preclinical and phase I studies. Absorption of even small amounts of lanthanum over a long period of time, however, may give rise to concern because of previous experience with aluminum. These issues, although not directly addressed in this report of 6 months' exposure, are currently being clarified in longer-term studies, lasting up to 3 years.

The results presented here corroborate findings from previous trials, which have indicated highly effective 
phosphate-binding characteristics and statistically and clinically significant reductions in phosphate levels over a similar dose range [22-24]. Significant changes in laboratory parameters (blood biochemistry and hematology) were also shown to be infrequent in patients treated with lanthanum carbonate. Importantly, serum calcium levels were generally not increased, as confirmed in this study $[22,23]$. This represents a significant advantage over calcium-based phosphate binders as it allows independent control of serum calcium and serum phosphate.

\section{Conclusions}

The results presented in this 6-month study demonstrate that serum phosphate control with lanthanum carbonate $(750-3,000 \mathrm{mg} /$ day lanthanum) is similar to that seen with calcium carbonate (1,500-9,000 mg/day), but with a significantly reduced incidence of hypercalcemia. Lanthanum carbonate is also well tolerated and may be more effective in reducing calcium $\times$ phosphate product than calcium carbonate. The combination of efficacy and tolerability demonstrated in this study suggests that lanthanum carbonate could represent a treatment option that is superior to calcium carbonate for hyperphosphatemia therapy. Longer-term studies are required to assess further the benefits of lanthanum carbonate and define its long-term safety profile.

\section{Acknowledgments}

The authors would like to thank the following investigators for their contributions to this study:

Belgium: Dr J.M. Billiouw, Aalst; Dr A.M. Bogaert, Zottegem; Prof. M.E. De Broe, Edegem; Dr B. De Moor, Hasselt; Dr M. De Paepe, Dendermonde; Dr R. Jamar, Bonheiden; Prof. N. Lameire, Aalst/Gent; Dr P.L. Leenaerts, Genk; Dr B. Maes, Leuven; Dr J.C. Stolear, Tournai.

Germany: Dr G. Asmus, Berlin; Dr P. Ausserehl, Oberhausen; Dr W. Backs, Hamburg; Dr W. Bagnewski, Dülmen; Dr R. Böhm, Aachen; Prof. W.H. Bösken, Trier; Dr A. Bosch, Worms; Dr D. Cortez-Campeao, Sinsheim; Prof. W. Därr, Berlin; Dr T. Döll, Hamburg; Dr O. Dörner, Idar Oberstein; Dr G.P. Dragoun, Aschaffenburg; Dr Fruehsorger, Bruchsal; Dr N. Graben, Essen; Dr H.P. Hild, Schwabach; Dr E.J. Kirchertz, Bad Münder; Dr U. Klehr, Bonn; Dr R. Krause, Berlin; Prof. J. Kult, Bad Mergentheim; Dr G. Leimenstoll, Kiel; Dr N. Luz, Amberg; Dr E. Meyer, Hamburg; Dr R. Miemietz, Mühlacker/Veihingen; Prof. G.A. Müller, Göttingen; Dr L. Musselmann, Rosenheim; Dr K.W. Ochlich, Heiligenstadt; Dr G. Prager, Bad König; Dr A. Raffelsiefer, Emsdetten; Dr E.H. Scheuermann, Frankfurt/Main; Prof. Dr H. Schiffl, Munich; Prof. Dr R. Schmieder, Nürnberg-Süd; Dr R. Scholz, Bad Homburg; Dr V. Schulz, Annweiler; Dr J. Schupp, Lauf; Prof. H. Thieler, Erfurt; Dr A. Vosskühler, Bottrop; Dr G. Warneke, Bovenden; Dr J. Woggan, Hamburg.

The Netherlands: Dr R.M. Huisman, Groningen; Dr M. Roggekamp, Amsterdam; Dr W. Van den Wall Bake, Veldhoven; Dr V. Verstappen, Venlo; Dr P.M. ter Wee, Amsterdam.

United Kingdom: Dr J. Bradley, Cambridge; Dr D.A. Davenport, London; Dr T. H.J. Goodship, Newcastle-upon-Tyne; Dr D. Hamilton, Norwich; Dr A.J. Hutchison, Manchester; Dr I. Khan, Aberdeen; Dr J. Kwan, Carshalton; Dr R. McGonigle, Plymouth; Dr A. Palmer, London; Dr H. Solomon, Preston; Dr N. Tamini, Canterbury; Dr P. Warwicker, Stevenage; Dr M. Wilkie, Sheffield; Prof. R. Wilkinson, Newcastle-upon-Tyne.

\section{References}

1 Block GA, Hulbert-Shearon TE, Levin NW, Port FK: Association of serum phosphorus and calcium $\times$ phosphate product with mortality risk in chronic hemodialysis patients: A national study. Am J Kidney Dis 1998;31:607617.

2 Goodman WG: Vascular calcification in chronic renal failure. Lancet 2001;358:1115-1116.

3 Mora Palma FJ, Ellis HA, Cook DB, Dewar JH, Ward MK, Wilkinson R, Kerr DN: Osteomalacia in patients with chronic renal failure before dialysis or transplantation. Q J Med 1983:52:332-348

4 Nilsson P: Bone disease in renal failure. Clinical and histomorphometric studies. Scand J Urol Nephrol 1984;84:1-68.

5 Drueke TB: Renal osteodystrophy: Management of hyperphosphataemia. Nephrol Dial Transplant 2000;15(suppl 5):32-33.
6 Hernandez P, Johnson CA: Deferoxamine for aluminum toxicity in dialysis patients. ANNA J 1990;17:224-228.

7 Gonzalez-Revalderia J, Casares M, de Paula M, Pascual T, Giner V, Miravalles E: Biochemical and hematological changes in low-level aluminum intoxication. Clin Chem Lab Med 2000;38:221-225.

8 Rob PM, Niederstadt C, Reusche E: Dementia in patients undergoing long-term dialysis: Aetiology, differential diagnoses, epidemiology and management. CNS Drugs 2001;15:691699.

9 Zacharias JM, Fontaine B, Fine A: Calcium use increases risk of calciphylaxis: A case-control study. Perit Dial Int 1999;19:248-252.

10 Martin KJ, Gonzalez EA: Strategies to minimize bone disease in renal failure. Am J Kidney Dis 2001;38:1430-1436.
$11 \mathrm{Hsu} \mathrm{CH}$ : Are we mismanaging calcium and phosphate metabolism in renal failure? Am J Kidney Dis 1997;29:641-649.

12 Sherrard DJ, Hercz G, Pei Y, Maloney NA, Greenwood C, Manuel A, Saiphoo C, Fenton $\mathrm{SS}$, Segre GV: The spectrum of bone disease in end-stage renal failure - An evolving disorder. Kidney Int 1993;43:436-442.

13 Chertow GM, Burke SK, Raggi P: Sevelamer attenuates the progression of coronary and aortic calcification in hemodialysis patients. Kidney Int 2002;62:245-252.

14 Chertow GM, Dillon M, Burke SK, Steg M, Bleyer AJ, Garrett BN, Domoto DT, Wilkes BM, Wombolt DG, Slatopolsky E: A randomized trial of sevelamer hydrochloride (RenaGel) with and without supplemental calcium. Strategies for the control of hyperphosphatemia and hyperparathyroidism in hemodialysis patients. Clin Nephrol 1999;51:18-26. 
15 Slatopolsky EA, Burke SK, Dillon MA: RenaGel, a non-absorbed calcium- and aluminumfree phosphate binder, lowers serum phosphorus and parathyroid hormone. The RenaGel Study Group. Kidney Int 1999;55:299-307.

16 Goldberg DI, Dillon MA, Slatopolsky EA, Garrett B, Gray JR, Marbury T, Weinberg M, Wombolt D, Burke SK: Effect of RenaGel, a non-absorbed, calcium- and aluminium-free phosphate binder, on serum phosphorus, calcium, and intact parathyroid hormone in endstage renal disease patients. Nephrol Dial Transplant 1998;13:2303-2310.

17 Indridason OS, Quarles LD: Hyperphosphatemia in end-stage renal disease. Adv Ren Replace Ther 2002;9:184-192.

18 Locatelli F, D’Amico M, Pontoriero G: Lanthanum carbonate. IDrugs 2003;6:688-695.

19 Damment SJP, Greaves P, Downes N: The toxicology of lanthanum carbonate (Fosrenol ${ }^{\circledR}$ ), a novel non-aluminum, non-calcium phosphate binder. 36th Annual Meeting of the American Society of Nephrology, San Diego 2003.
20 Damment SJP, Webster I: The pharmacology of lanthanum carbonate $\left(\right.$ Fosrenol $\left.{ }^{\circledR}\right)$ : A novel non-aluminium, non-calcium phosphate binder. 36th Annual Meeting of the American Society of Nephrology, San Diego 2003.

21 Pennick M, Damment SJP, Gill M: The new non-aluminium, non-calcium phosphate binder, lanthanum carbonate, demonstrates pharmacokinetics favourable for use in a chronic kidney disease population. XLI ERA-EDTA Congress, Lisbon, May 2004.

22 Hutchison AJ, Speake M, Al-Baaj F: Reducing high phosphate levels in patients with chronic renal failure undergoing dialysis: A 4-week, dose-finding, open-label study with lanthanum carbonate. Nephrol Dial Transplant 2004; 19: 1902-1906.

23 Joy MS, Finn WF: Randomized, double-blind, placebo-controlled, dose-titration, phase III study assessing the efficacy and tolerability of lanthanum carbonate: A new phosphate binder for the treatment of hyperphosphatemia. Am J Kidney Dis 2003;42:96-107.

24 Finn WF, Joy MS, Hladik GA: Results of a randomized dose-ranging, placebo-controlled study of lanthanum carbonate for reduction of serum phosphate in chronic renal failure patients receiving hemodialysis. Clin Nephrol 2004;62:193-201.
25 Grohse PM, Giglio JJ, O'Rourke JA, Giglio TC, Burnett TD: The determination of lanthanum in human plasma using inductively coupled plasma mass spectrometry (ICP-MS). 12th International Symposium on Pharmaceutical and Biomedical Analysis (PBA), Monterey, Calif, 2001.

26 Goodman WG, Goldin J, Kuizon BD, Yoon C, Gales B, Sider D, Wang Y, Chung J, Emerick A, Greaser L, Elashoff RM, Salusky IB: Coronary-artery calcification in young adults with end-stage renal disease who are undergoing dialysis. N Engl J Med 2000;342:14781483.

27 Ganesh SK, Stack AG, Levin NW, HulbertShearon T, Port FK: Association of elevated serum $\mathrm{PO}_{4}, \mathrm{Ca} \times \mathrm{PO}_{4}$ product, and parathyroid hormone with cardiac mortality risk in chronic hemodialysis patients. J Am Soc Nephrol 2001;12:2131-2138. 